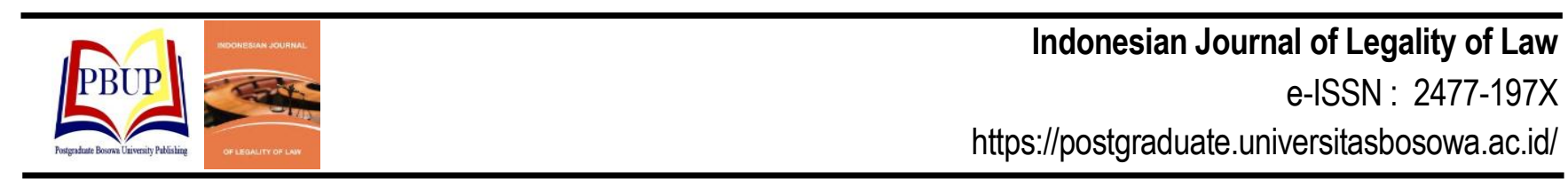

\title{
ANALISIS HUKUM PEMENUHAN HAK KONSUMEN ATAS INFORMASI PRODUK HALAL PADA RESTORAN DI KOTA MAKASSAR
}

\author{
Legal Analysis of Fulfilling Consumer Rights to Information on Halal Products at Restaurants in \\ Makassar City
}

\author{
Nurlela $^{1}$, Andi Muhammad Arfah Pattenreng ${ }^{1}$, Abd. Hamid Haris ${ }^{1}$ \\ ${ }^{1}$ Program Studi Ilmu Hukum Program Pascasarjana Universitas Bosowa \\ Email:vhyka99@gmail.com
}

Diterima: 12 Mei 2020/Disetujui: 05 Juni 2020

\begin{abstract}
ABSTRAK
Penelitian ini betujuan untuk mengetahui pelaksanaan pemenuhan hak konsumen atas informasi produk halal pada Restoran di Kota Makassar dan faktor yang mempengaruhi ketidakterpenuhan hak konsumen atas informasi produk halal pada Restoran di Kota Makassar. Penelitian ini dilakukan di Kota Makassar, dengan lokasi penelitian khususnya pada kantor LPPOM MUI, dan di beberapa Restoran. Metode yang penulis gunakan adalah peneliian kualitataif dengan tujuan untuk menguji pelaksanaan pemenuhan hak konsumen atas informasi produk halal pada Restoran di Kota Makassar dan faktor yang mempengaruhi ketidakterpenuhan hak konsumen atas informasi produk halal pada Restoran di Kota Makassar. Penelitian ini dilakukan di Kota Makassar, dengan lokasi penelitian khususnya pada kantor LPPOM MUI, dan di beberapa Restoran Hasil penelitian menunjukkan bahwa Pelaksanaan pemenuhan hak konsumen atas informasi produk halal pada restoran di Kota Makassar telah dilaksanakan namun, belum efektif. Adapun faktor yang mempengaruhi ketidakterpenuhan hak konsumen atas informasi produk halal pada Restoran di Kota Makassar adalah, Pemerintah dalam hal ini Badan Pelaksana Jaminan Produk Halal (BPJPH) tidak bisa melaksanakan fungsinya dalam melakukan pembinaan dan pengawasan terhadap jaminan produk halal di Kota Makassar mengingat lembaga ini hanya ada di Pusat, tidak ada di daerah Kabupaten/Kota, Restoran/pelaku usaha yang ada di Kota Makassar cenderung mengabaikan hak konsumen dengan tidak menyampaikan keadaan kehalalan produk yang mereka sajikan dan konsumen cenderung melihat dari sisi pemilik dan pegawai restoran. Umumnya, mereka tidak memiliki sikap kritis, sehingga kadang abai dari memperhatikan masalah kehalalan produk yang disediakan di restoran. Padahal itu dapat merugikan mereka sebagai konsumen.
\end{abstract}

Kata Kunci: Hak Konsumen, Jaminan Produk Halal, Sertifikat Halal

\begin{abstract}
This research was conducted in Makassar City, precisely at the office of LPPOM MUI, and in some restaurants. The method used by the author is a qualified study with the aim to test the fulfillment of consumer rights for halal product information at restaurants in Makassar City and the factors that affect the unenforceability of consumer rights of halal product information at restaurants in Makassar City. The results showed that the implementation of consumer rights fulfillment of halal product information at restaurants in Makassar City has been implemented, however, not yet effective. The factors that influence the unterpenes of consumer rights of halal product information at the restaurants in Makassar City are that the government in the implementation of Halal Product Guarantee (BPJPH) cannot carry out its function in conducting construction and supervision of halal product guarantee in Makassar City considering that the institution is only in the center, not in the district/city, restaurants/business owners in Makassar City who tend to ignore the rights of consumers by not convey the circumstances of the products they serve, and consumers who tend to see from the side of the restaurant owners and employees. Generally, they do not have a critical attitude, so sometimes they neglect to pay attention to the problem of the products provided at the restaurants. Indeed, it can harm them as consumers.
\end{abstract}

Keywords: Consumer Rights Protection, Halal Product Guarantee, Halal Certificate

\section{PENDAHULUAN}

Makanan merupakan kebutuhan pokok manusia adalah segala sesuatu yang berasal dari sumber hayati dan air, baik yang diolah maupun tidak diolah, yang diperuntukan sebagai makanan atau minuman bagi konsumsi manusia, termasuk bahan tambahan pangan, bakan baku pangan, dan bahan lain yang digunakan dalam proses penyiapan, pengolahan, dan/atau pembuatan makanan dan minuman (Zulham, 2013). Olehnya itu ketersediaannya harus selalu diusahan. Salah satu cara agar keberadaan makan dengan diproduksi oleh pelaku 
usaha di retoran. Denga tesedianya makanan di restoran, masyarakat konsumen dapat memenuhi kebutuhanya. Dari transaksi tersebut kemudian dapat meningkatkan perekonmian masyarakat utamanya pelaku usaha atau konsumen karena mendapatkan keuntungan. Dengan mengejar keuntungan, pelaku usaha kadang menggunakan berbagai cara untuk menaik minat konsumen. Kadang melakukan cara yang dapat mergikan pihak konsumen karena konsumen kadang memiiki kedudukan yang lemah.

Makanan halal adalah pangan yang tidak mengandung unsur atau bahan yang haram atau dilarang untuk dikonsumsi umat Islam, baik yang menyangkut bahan baku pangan, bahan tambahan pangan, bahan bantu dan bahan penolong lainnya termasuk bahan pangan yang dioleh melalui proses rekayasa genetika dan iradia pangan, dan yang pengelolaannya dilakukan sesuai dengan ketentuan hukum agama Islam (Pasal 1 angka 5 PP No. 69 Tahun 1999 tentang Label dan Iklan).

Amin (2013) menyatakan bahwa makanan halalharam bukan hanya masalah umat muslim saja, melainkan juga berkaitan dengan masyarakat luas pada umumnya. Karena itu, agar ibadah dan doa diterima oleh Allah, maka harus berusaha semaksimal mungkin agra makanan dan minuman yang dikonsumsi terjamin halâl dan thayyib-nya, sebagai bagian dari syarat diterimanya ibadah dan doa. Jaih Mubarok (Mubarok, 2006) mengemukakan bahwa membicarakan halal-haram lebih banyak berhubungan dengan makanan, minuman, dan pakaian. Oleh sebab itu, menggunakan atau mengkonsumsi produk halal menurut keyakinan agama (Islam) dan/atau demi kualitas hidup dan kehidupan, merupakan hak warga negara yang dijamin oleh UndangUndang Dasar 1945 (Mashudi, 2015)

Pasal 2 Undang-Undang Nomor 8 Tahun 1999 tentang Perlindungan Konsumen menyatakan, perlindungan konsumen berasaskan manfaat, keadilan, keseimbangan, keamanan dan keselamatan konsumen serta kepastian hukum (Ahmadi Miru \& Sutarman Yodo, 2015). Perlindungan terhadap konsumen dipandang sangatlah penting, mengingat semakin banyaknya pelanggaran yang sering diakukan oleh pelaku usaha. Apabila membahas mengenai dan minuman maka, restoran merupakan sesuatu yang tidak bisa lepas dari pembahasan tersebut mengingat tempat di tempat inilah makanan dan minuman dijual. Salah satu yang penting diperhatikan dalam hal makanan adalah tentang kehalalan. Karena saat ini sekarang ini, masih banyak restoran yang menjual makanan dan minuman yang dipertanykan akan kehalalannya. Hal itu terjadi karena restoran tersebut tidak memunyai sertifikat halal dari MUI.

Hukum perlindungan konsumen yang menjadi permasalahan adalah bagaimana ketentuan-ketentuan hukum dan menjalankan usahanya para pelaku usaha sedapat mungkin tidak merugikan konsumen dan bagaimana para konsumen dapat dilindungi hak-haknya sebagai konsumen. Demi melindungi konsumen, maka pelaku usaha restoran harus mengikuti standar dalam memproduksi produknya dan pemerintah memegang peran penting terhadap penerapan standarisasi produk, pembinaan dan pengawasan produksi, serta pendistribusian suatu produk.

Berdasakan Undang-Undang Nomor 8 Tahun 1999 tentang Pelindungan Konsumen (UU PK) Pasal 4 disebtkan bahwa hak konsumen adalah
1) Hak atas kenyamanan, keamanan dan keselamatan dalam mengkomsumsi barang dan/atau jasa.

2) Hak untuk memilih dan mendapatkan barang dan/atau jasa sesuai dengan nilai tukar dan kondisi serta jaminan yang dijanjikan.

3) Hak atas informasi yang benar, jelas, dan jujur mengenai kondisi dan jaminan barang dan/atau jasa

4) Hak untuk didengar pendapat dan keluhannya atas barang dan/atau jasa yang digunakan.

5) Hak untuk mendapatkan advokasi, perlindungan, dan upaya penyelesaian sengketa perlindungan konsumen secara patut.

6) Hak untuk mendapat pembinaan dan pendidikan konsumen.

7) Hak untuk diperlakukan atau dilayani secara benar dan jujur serta tidak diskriminatif .

8) Hak untuk mendapatkan kompensasi, ganti rugi, dan/atau penggantian, apabila barang dan/atau jasa yang diterima tidak sesuai dengan perjanjian atau tidak sebagaimana mestinya.

9) Hak-hak yang diatur dalam ketentuan peraturan perundang-undangan lainnya.

Beberapa hak yang diberkan oleh UU kepada konsumen tesebut di atas merupakan kewajiban bagi pelaku usaha untuk dapat mewujudkanya. Salah satu hak tersebut adalah hak untuk mendapatkan informasi yang benar, jelas, dan jujur mengenai kondisi dan jaminan barang dan/atau jasa dari pelaku usaha. Hak tersebut termasuk mendapatkan infomasi yang benar mengenai kehalalan produk.

Mengenai kehalalan akan suatu produk yang dijual oleh pelaku usaha, dalam Undang-Undang Nomor 33 Tahun 2014 tentang Jaminan Produk Halal (UU JPH) disebutkan bahwa pada dasarnya, semua produk yang akan dijual di Indonesia adalah produk yang halal, maka wajib diperoleh bersertifikat halal. Pengesahan label halal oleh BPJPH terdapat dapat dilihat pada Pasal 37 UU JPH. Banyaknya produk yang tidak berlabel halal sangatlah meresahkan masyarakat, karena pencantuman label halal menjadi tolok ukur masyarakat muslim untuk mamakai, menggunakan atau mengkonsumsi produk tersebut. Banyak produk makanan dalam negeri maupun luar negeri yang dijual di Indonesia namum belum dicantumkannya label halal atau tidak halal pada produk tersebut walaupun makanan tersebut memang haram dikonsumsi masyarakat muslim di Indonesia. Meski sudah diatur dalam regulasi, kenyataannya masih sangat kurang restoran yang mempunyai sertifikat halal.

Mashudi (2015) menyatakan bahwa pemerintah telah merespon secara positif pentingnya sertifikasi dan pencantuman tanda atau tulisan halal pada produk (labelisasi halal) melalui beberapa regulasi. Akan tetapi, regulasi ini masih terkesan sektoral dan parsial. Padahal, pangan sebagai kebutuhan dasar manusia yang pemenuhannya merupakan hak asasi setiap rakyat Indonesia harus senantiasa tersedia cukup setiap waktu, aman, bermutu, bergizi, dan beragam dengan harga yang terjangkau oleh daya beli masyarakat (Departemen Agama, 2003: 310), perlu mendapat perlindungan hukum dan jaminan kepastian hukum kehalalan untuk dikonsumsi, terutama umat Islam yang wajib dilindungi dan diberi hak menjalankan ibadah seusai dengan manat UUD 1945 terutama Pasal 28 dan 29 (Hazairin, 1990) 


\section{METODE}

\subsection{Jenis Penelitian}

Penelitian yang penulis lakukan ini, merupakan penelitian empiris yaitu yang mengkaji tentang penomena hukum yang berhubungan dengan pemenuhan hak konusumen atas informasi produk halal pada restoan. Disamping itu penelitian empiris tersebut dengan menggunakan pendekatan hukum (yuridis) agar sesuai peraturan perundang-undangan yang berhubungan dengan pemenuhan hak konusumen.

\subsection{Jenis dan Sumber Data}

Dalam penelitian ini, penulis menggunkan dua jenis data yaitu: data primer dan data sekunder. Data primer merupakan data yang didapatkan secara langsung dari hasil wawancara dan kuisioner/angket dengan pihak yang terkait yang telah ditetapkan. Sedangkan data sekunder adalah data yang didapatkan dari penelusuran bahan pustaka seperti: buku, karya dan artikel ilmiah, hasil penelitian dan lain-lain.

\subsection{Teknik Pengumpulan Data}

Penelitian ini menggunkan teknik pengumpulan data dengan cara melakukan wawancara (interview) dan mnyebarkan kuisioner/angket kepada pihak yang terkait dengan pemenuhan hak konsumen atas informasi produk halal pada restoran di Kota Makassar, dalam hal ini pihak LPPOM MUI Propinsi Sulawesi Selatan, Pelaku Usaha Restoran dan pelanggan restoran seagai konsumen di Kota Makassar.

\section{HASIL DAN PEMBAHASAN}

\subsection{Pelaksanaan Pemenuhan Hak Konsumen Atas Informasi Produk Halal pada Restoran di Kota Makassar}

Hak konsumen atas informasi produk halal sangatlah penting, agar tidak ada keraguan pada saat ingin mengkonsumsi suatu produk khususnya makanan yang disajikan oleh pelaku usaha untuk konsumen.Sebagai pelaku usaha khususnya dibidang restoran harus memberikan ketenangan jiwa kepada konsumen. Pelaksanaan yang mestinya dilakukan oleh para pelaku usaha restoran harus mengacu pada Pasal 25 huruf a UU JPH yang berbunyi bahwa "Pelaku Usaha yang telah memperoleh Sertifikat Halal wajib mencantumkan Label Halal terhadap Produk yang telah mendapat Sertifikat Halal."

BPJPH merupakan sebuah lembaga yang dibentuk oleh pemerintah yang ditugaskan untuk mengurusi urusan terkait jaminan produk halal di Indonesia. Badan ini berada di bawah naungan Kementerian Agama serta bertanggungjawab kepada menteri Agama. Menurut Pasal 6 huruf e UUJPH, bahwa ada beberapa kewenangan yang dimiliki oleh BPJPH dalam penyelenggaraan jaminan produk halal di Indonesia. Kewenangan tersebut adalah: (1) melakukan sosialisasi, (2) edukasi, dan (3) publikasi Produk Halal. Adapun kegiatan yang dilakukan BPJPH kerjasama LPPOM MUI yaitu:

a) Sosialisasi

Untuk memberikan pemahaman kepada masyarakat, sosialisasi dan promosi halal sangat diperlukan. Melalui kegiatan tersebut, diharapkan masyarakat sebagai konsumen maupun sebagai pelaku usaha mengerti, memahami dan dapat menerapkan gaya hodup halal dalam kehidupan sehari-sehari. Adapun berbagai macam program kegiatan yang dilakukan oleh BPJPH oleh LPPOM MUI dalam mensosialisasikan dan mempromosikan jaminan halal kepada masyarakat.

Seperti yang dikatakan oleh Jamaluddin Saleh bahwa: "Ada berbagai cara yang kami lakukan untuk mensosialisasikan pemenuhan hak konsumen atas informasi produk halal Pada Restoran di Kota Makassar. Cara tersebut dibuat dalam bentuk kegiatan yang melibatkan masyarakat sebagai konsumen dan pihak restoran sebagai pelaku usaha."

Berdasarkan hasil wawancara dengan Jamaluddin Saleh selaku Wakil Direktur Kesekretariatan LPPOM MUI Propinsi Sulawesi Selatan, bahwa hal-hal yang dilakukan oleh BPJPH kerjasama dengan LPPOM MUI dalam mensosialisasikan pemenuhan hak konsumen atas informasi produk halal adalah sebagai berikut:

1) Indonesia International Halal Expo (INDHEX)

Demi memberikan pemahaman dan pengenalan produk yang bersertifikat halal, LPPOM MUI menyelenggarakan kegiatan atau event tahunan yang disebut INDHEX. Evant tersebut berupa Expo produk yang bersertifikat Halal dan berbagai event lain seperti Global Halal Forum, Halal Award.

2) Olimpiade Halal

Untuk semakin meningkatkan pengetahuan masyarakat akan produk halal, LPPOM MUI melaksanakan Olimpiade Halal. Kegiatan tersebut diikuti para peserta dari kalangan pelajar SMU. Olimpiade tersebut terbuka bagi seluruh SMU secara Nasional. Agar kegiatan ini dapat meningkatkan kepedulian dan menumbuhkan pengetahuan generasi muda akan produk halal sehinga mereka dapat menerapkan gaya hidup halal "Halal is $M y$ Life" dalam kehidupannya sehari-hari. Dengan demikian, kegiatan ini digelar setiap tahun. Dalam olimpiade ini, para peserta mengikuti ujian. Ujian dilakukan melalui program Halal Learning Online (HALO) LPPOM MUI

3) Halal Food Goes to School

Kegiatan ini diharapkan agar generasi muda mempunyai kepedulian akan pentingnya produk halal dan mengkonsumsi makanan, minuman maupun menggunakan jasa yang halal. Program ini dikemas dalam bentuk penyuluhan kepada anak sekolah dengan mendatangi langsung mereka ke sekolah-sekolah, mulai tingkat TK hingga tingkat SMA/sederajat dengan cara memperkenalkan akan pentingnya produk halal.

4) Wisata Halal (Halal Tour)

Kegiatan ini dilakukan dengan cara memperkenalkan kepada anak usia sekolah dan masyarakat umum tentang cara proses pengolahan makanan dan minuman halal serta memberikan pengetahuan mengenai kehalalan suatu produk di perusahaan yang sudah memperoleh sertifikat halal.

5) Seminar/Talkshow Halal

Kegiatan ini dilakukan dengan cara LPPOM MUI bekerjasama dengan berbagai pihak seperti universitas, instansi pemerintah maupun swasta dan media dalam melaksanakan kegiatan seminar/talkshow di universitas maupun istansi masing-masing

6) Halal Competition

Demi untuk menigkatkan kesadaran dan kepedulian masyarakat akan produk halal, maka diadakan kegiatan kompetisi halal dengan melalui penumbuhan kreativitas dalam berbagai aneka lomba halal. Lomba ini, telah dilaksanakan dari tahun ke tahun. Adapun jenis lomba setiap tahunnya adalah : Lomba Blog Halal, Halal Hijab Life Style bekerjasama dengan forum detik, Lomba Kreativitas Halal Mom \& Me bekerja sama dengan Majalah Ummi, dan Lomba Foto Hijab Foto Hunting

7) Fasilitasi Sertifikasi Halal Gratis 
Salah satu kendala dalam mendapatkan serifikat halal bagi pelaku usaha adalah adanya biaya yang harus dibayar demi untuk memperoleh sertifikat halal. Olehnya itu, LP POM MUI bersinergi dengan berbagai lembaga/Instansi Pemerintah seperti Kementrerian Agama, Badan Pemeriksa Obat dan Makanan, Kementerian KUKM, Dinas Perindustrian Kabupaten/Kota, Pemerintah/Instansi demi untuk memberikan sertifikasi halal gratis kepada masyarakat pelaku usaha kecil dan menengah.

8) Sosialisasi Halal Kepada UKM/Perusahaan Besar

Demi memberikan pemahaman terhadap pentingnya sertifikasi produk halal bagi para pelaku usaha baik perusahaan kecil maupun perusahaan besar, diadakan sosialisasi kepada mereka. Sosialisasi ini dilaksanakan dengan mandiri maupun bekerja sama dengan berbagai pihak termasuk pemerintah/Instansi terkait, LPPOM MUI memberikan sosialisasi halal kepada UKM maupun Perusahaan Besar agar pelaku usaha ini menerapkan produk halal yang mereka produksi.

9) Sosialisasi Halal melalui Media dan Sosial Media

Agar informasi produk halal semakin diketahui dan dilaksanakan oleh masyarakat, baik pelaku usaha maupun konsumen, LPPOM MUI mengadakan sosialisasi dengan melibatkan media yang ada, baik media baik cetak, elektronik maupun media online seperti: Republika, Detik.Com, Majalah Ummi, dll dalam mensosialisasikan produk halal. Selain itu, LPPOM MUI juga menggunakan sosial twiter dan ficebook untuk melakukan sosialisasi halal. twitter yang digunakan dengan nama @ HalalIndonesia sementara Facebook dengan nama: Halal MUI.

10) Merchandise

LPPOM MUI menciptakan berbagai merchandise dengan tagline "Halal is My Life" hal itu dilakukan sebagai upaya sosialisasi kepada masyarakat.

Adapun dari hasil penyebaran angket kepada produsen yang dilakukan oleh peneliti, mengenai tanggapan-tanggapan dari produsen tentang informasiproduk halal:

Tabel 1

Tanggapan Responden Mengenai Apakah Sudah Mendapatkan Sosialisasi Produk Halal

\begin{tabular}{clcc}
\hline No & $\begin{array}{c}\text { Jawaban } \\
\text { Responden }\end{array}$ & Frekuensi & Persentase \\
\hline 1 & Sudah & 20 & $40 \%$ \\
2 & Belum & 11 & $22 \%$ \\
3 & Tidak Tahu & 19 & $38 \%$ \\
\hline & Jumlah & 50 & $100 \%$
\end{tabular}

Sumber : Data Primer 2020

Berdasarkan Tabel 1. di atas, tanggapan responden mengenai sosialisasi yang telah dilakukan oleh LPPOM MUI, apakah sudah berjalan dengan baik atau belum, yang menjawab sudah berjalan dengan baik sebanyak 20 responden (40\%), kemudianyang menjawab belum baik sebanyak 11 responden $(22 \%)$, dan yang menjawab tidak tahu mengenai ada atau tidaknya sosialisasi yang dilakukan oleh LPPOM MUI sebanyak 19 responden (38\%). Dari hasil yang di dapat oleh penulis, yaitu responden yang menjawab sudah berjalan dengan baik sekitar 20 responden $(40 \%)$, dari hasil tersebut menunjukkan bahwa sosialisasi yang dilakukan oleh LPPOM MUI belum berjalan dengan baik.

\section{b) Hak Informasi}

Memperoleh informasi merupakan hak yang dimiliki oleh warga negara yang dijamin dalam Undang-Undang Dasar Negara Republik Indonesia Tahun 1945 Pasal 28 F yang berbunyi bahwa "Setiap orang berhak untuk berkomunikasi dan memperoleh informasi untuk mengembangkan pribadi dan lingkungan sosialnya, serta berhak untuk mencari, memperoleh, memiliki, menyiman, mengolah dan menyampaikan informasi dengan menggunakan segala jenis saluran yang ada."

Semantara dalam UUPK Pasal 4 ayat (3) disebutkan bahwa "hak atas informasi yang benar, jelas, dan jujur mengenai kondisi dan jaminan barang dan/jasa." Dari bunyi Peraturan Perundang-undangan dapat dipahami bahwa mendapatkan informasi bagi konsumen merupakan hak yang harus dipenuhi oleh pelaku usaha, termasuk mendapatkan informasi mengenai kehalalan suatu produk yang akan dikomsumsi oleh konsumen di restoran.

Pemenuhan hak informasi ini harus dilakukan oleh negara dalam hal ini tugas tersebut diemban oleh LPPOM MUI dan BPJPH serta restoran sebagai pelaku usaha. Adapun pemenuhan hak informasi akan produk halal yang dilakukan LPPOM MUI kepada masyarakat sebagai konsumen yakni dengan cara mengumumkan malalui media yang ada.seperti yang dikatakan oleh Jamaluddin Saleh Wakil direktur LPPOM MUI Sulawesi Selatan (Wawancara, 3 Mei 2019) bahwa: "Selain sosialisasi, kami pun melakukan pengumuman. Adapun pengumuman yang kami lakukan agar pemenuhan hak konsumen atas informasi produk halal adalah dengan menggunakan media, yaitu media penyiaran radio dan brosur.

Dengan menggunakan media radio yang ada di Kota Makassar, kami menyiarkan dan mengiklankan mengenai produk halal dan sertifikat halal kepada masyarakat akan pentingnya memilih suatu produk yang telah berlabel halal,terutama konsumen muslim pada semua produk yang akan dikonsumsi di setiap restoran yang ada di Kota Makassar. Sementara dengan brosur, kami menyebarkan brosur untuk menginformasikan kepada masyarakat bahwa ada produk halal yang ditandai dengan sertifikat halal pada produkdengan nomor yang dicantumkan bagi semua produk yang sudah lolos uji sesuai ketentuan dari LPPOM MUI.Dengan nomor tersebut, sebagai bukti keaslian suatu produk yang telah bersertifikat halal.Dengan begitu, konsumendapat menghilangkan kekhawatiran dan keraguan terhadap suatu produk yang ingin dikonsumsi."

Berdasarkan hasil wawancara yang telah penulis lakukan tersebut di atas, dapat diketahui bahwa pelaksanaan pemenuhan hak konsumen atas informasi produk halal pada restoran di Kota Makassar telah dilakukan oleh lembaga yang berwenang yakni LPPOM MUI Sulsel dan BPJPH di pusat.

Tabel 2

Tanggapan Responden Terkait Pemenuhan Hak Informasi

\begin{tabular}{clcc}
\hline No & $\begin{array}{c}\text { Jawaban } \\
\text { Responden }\end{array}$ & Frekuensi & Persentase \\
\hline 1 & Sudah & 8 & $16 \%$ \\
2 & Belum & 33 & $66 \%$ \\
3 & Tidak Tahu & 9 & $18 \%$ \\
\hline & Jumlah & 50 & $100 \%$ \\
\hline
\end{tabular}

Sumber : Data Primer 2020 
3.1 Faktor yang Mempengaruhi Ketidakterpenuhan Hak Konsumen Atas Informasi Produk Halalpada Restoran di Kota Makassar

a) Pemerintah

Badan Penyelenggara Jaminan Produk Halal (BPJPH) merupakan badan yang mewakili pemerintah dalam urusan jaminan produk halal di Indonesia. UU JPH pada BAB VIII yaitu Pengawasan yang dilakukan oleh BPJPH tidak lepas juga membutuhkan peran serta masyarakat dalam membantu BPJPH untuk melihat para pelaku usaha agar tidak melakukan pelanggaran-pelanggaran yang tidak sesuai dan sudah ditetapkan oleh UUJPH. Pada Pasal 53 ayat (3) UU JPH bahwa "peran serta masyarakat berupa pengawasan Produk dan Produk Halal yang beredar sebagaimana dimaksud pada ayat (2) huruf byang berbentuk pengaduan atau pelaporan ke BPJPH."

UU tersebut, memberikan peluang kepada masyarakat untuk membantu BPJPH dalam pengawasan terhadap produk dan produk halal yang beredar, tetapi pada kenyataannya masih banyak masyarakat yang tidak mengetahui mengenai UU tersebut, bahwa masyarakat dapat berperan serta dalam membantu BPJPH. Adapun masyarakat yang mengetahui dan memahami mengenai UU tersebut, tidak melakukan tindakan apapun ketika terdapat pelanggaran yang dilakukan oleh pelaku usaha yang melanggar UUJPH, sehingga tidak tercapailah pemenuhan hak konsumen atas informasi produk halal khususnya di bidang restoran yang ada di Kota Makassar. Padahal dalam Pasal 54 UUJPH di tentukan bahwa BPJPH dapat memberikan penghargaan kepada masyarakat yang berperan serta dalam penyelenggaraan JPH. Dalam hal ini, Pemerintah juga sudah mengeluarkan Undang-Undang Nomor 8 Tahun 1999 tentang Perlindungan Konsumen (UUPK). Dalam UUPK Pasal 30 ayat (3) yang mengatur mengenai pengawasan. UUPK menyebutkan, bahwa "pengawasan oleh masyarakat dan LPKSM dilakukan terhadap barang dan/atau jasa yang beredar di pasar" sementara menurut Pasal 8 ayat (1) Peraturan Pemerintah tentang Pembinaan dan Pengawasan Penyelenggaraan Perlindungan Konsumen, bahwa "Pengawasan oleh pemerintah dilakukan terhadap pelaku usaha dalam memenuhi standar mutu produksi barang dan/atau jasa, pencantuman label dan klausula baku, serta pelayanan purna jual barang dan/atau jasa." Dengan demikian, pengawasan oleh pemerintah di lakukan berdasarkan pasal tersebut di atas, setelah hasil pengawasan di dapatkan, maka dapat di sebarluaskan ke masyarakat yang termuat di dalam Pasal 8 ayat (3) bahwa hasil pengawasan sebagaimana dimaksud dalam ayat (2) dapat disebarluaskan kepada masyarakat.

Adapun dalam UUPK disebutkan bahwa pengawasan dapat dilakukan oleh masyarakat dan LPKSM untuk memberikan kemudahan kepada masyarakat untuk mendapatkan hak-haknya dalam mengkonsumsi suatu barang, tetapi pengawasan yang dilakukan tidak seimbang antara masyarakat dan lembaga swadaya masyarakat dalam mengawasi produk barang yang beredar. Kurangnya kesadaran dari masyarakat akan pentingnya pengawasan tersebut sehingga masih belum dapat memenuhi hak-hak konsumen dalam mengkonsumsi suatu produk pagan.

b) Restoran/Pelaku Usaha

Kota Makassar sebagai salah satu kota yang melangami perkembangan yang cukup pesat dan merupakan salah satu kota pusat bisnis di Kawasan Timur Indonesia, tentunya memiliki banyak badan usaha termasuk restoran. Adapun jumlah restoran yang ada di Kota Makassar dapat dilihat pada tabel berikut ini:

Tabel 3

Jumlah Restoran yang Ada di Kota Makassar Perkecamatan

\begin{tabular}{clc}
\hline No & Kecamatan & Jumlah Restoran \\
\hline 1 & Mariso & 85 Restoran \\
2 & Mamajang & 158 Restoran \\
3 & Makassar & 121 Restoran \\
4 & Ujung Pandang & 294 Restoran \\
5 & Wajo & 179 Restoran \\
6 & Bontoala & 56 Restoran \\
7 & Tallo & 34 Restoran \\
8 & Ujung Tanah & 7 Restoran \\
9 & Panakkukang & 465 Restoran \\
10 & Tamalate & 218 Restoran \\
11 & Biringkanaya & 153 Restoran \\
12 & Rappocini & 282 Restoran \\
13 & Manggala & 62 Restoran \\
14 & Tamalanrea & 160 Restoran \\
\hline & Jumlah Total & 2.274 Restoran
\end{tabular}

Sumber :Dinas Pendapatan Daerah Kota Makassar, 2019

Berdasarkan Tabel 3 di atas, hasil yang peneliti dapatkan dari Dinas Pendapatan Daerah Kota Makassar bagian Kepala Seksi Pendataan Bidang Pajak Restoran. Kota Makassar memiliki 14 Kecamatan dari seluruh kecamatan yang ada, jumlah restoran yang ada saat ini sekitar 2.274 restoran. Dari keseluruhan restoran yang ada di Kota Makassar, tidak semua memunyai sertifikat halal. Adapun prestoran yang memiliki sertifikat halal di Kota Makassar dapat dilihat pada Tabel 4.

Tabel 4

Daftar Catering, Rumah Makan, Restoran, Kantin Dan Dapur Hotel Masih Berlaku Sertifikat Halalnya Per-3 Mei 2019

\begin{tabular}{cllcc}
\hline No & \multicolumn{1}{c}{ Nama Perusahaan } & \multicolumn{1}{c}{ Alamat Perusahaan } & Jenis Produk & Keterangan \\
\hline 1 & CV .Rumahan Sukses & Jl.Datumuseng No. 52 C, Kec. Ujung Pandang. Makassar & Catering & Bersertifikat Halal \\
2 & CV.Adly Putra Perdana & Jl.Gunung Bawakaraeng No.125 C, Kec. Makassar & Catering & Bersertifikat Halal \\
3 & Aston Makassar Hotel \& & Jl.Sultan Hasanuddin No.10, Kec. Somba Opu. Makassar & Dapur Hotel & Bersertifikat Halal \\
& Convention Center & Jl.Poros Asrama Haji No.8 Sudiang, Kec. Biringkanaya. Makassar & Catering & Bersertifikat Halal \\
4 & CV.Arky & Jl.Perintis Perkasa Mandiri, Kec. Tamalanrea. Makassar & Catering & Bersertifikat Halal \\
5 & CV.Putra Perkasa Mandiri & Catering & Bersertifikat Halal \\
6 & CV.F3 Bersaudara & Jl.Maccini Kidul No.39, Kec. Makassar & Catering & Bersertifikat Halal \\
7 & CV.Nurhikmah & Jl.Lanto Daeng Pasewang No.59 A, Kec. Ujung Pandang. Makassar & Catering & Bersertifikat Halal \\
8 & RM.Pondok Bambu & Jl.Gowa Ria No.10 Sudiang, Kec. Biringkanaya. Makassar & Catering & Bersertifikat Halal \\
9 & CV.Aksan Jaya & Jl.Abu Bakar Lambogo No.4-6, Kec. Makassar & Dapur Hotel & Bersertifikat Halal \\
10 & Pesona Hotel Makassar & Jl.Andi Mappanyuki No.49, Kec. Mariso. Makassar & Catering & Bersertifikat Halal \\
11 & CV.Nani & Jl.Sultan Alauddin, Komp. Permata Sari 6/10, Kec. Tamalate. & Catering & Bersertifikat Halal \\
& & CV.Reight Lil Alamin & Perumahan BPH, Jl.Bumi II No.9, Kec. Rappocini. Makassar & Cararing
\end{tabular}


13 Catering Bunda Azka

14 CV.Naurah Mitra Abadi

15 PT.Parewa Jaya Catering

16 Claro Hotel Makassar

17 Almadera Makassar

18 CV.Condong Raos

19 CV.Sheila Pratama

20 CV.Catering Dapur Pesona

21 CV.Fatimah Catering

22 CV.Glory

23 CV.Rezky Jaya

24 Dalton Makassar

25 PT.Rezky Erlima Pramata
Jl.Mongonsidi Baru No.26, Kec. Makassar

Jl.Puri Taman Sari Blok F5, No.19, Kec. Manggala. Kota Makassar

Jl.Perintis Kemerdekaan Km.19 Ruko 237 No.1-2 Sudiang, Kec.

Biringkanaya. Makassar

Jl.AP.Pettarani No.3 Lt.2, Kec. Panakkukang. Makassar

Jl. Somba Opu No.235 Lt.1, Kec. Ujung Pandang. Makassar

Jl. Pelita Raya Tengah Blok A6 B No.5B, Kec. Rappocini.Makassar

Jl.Bontoduri I Perm.Green House Alauddin/A9, Kec. Tamalate.

Makassar

Jl. Dg.Tata,BT. Hartaco Indah Blok IV C/9, Kec. Tamalate.

Makassar

Jl. Jipang Raya, Perum Bumi Palem R.17, Kec. Rappocini.

Makassar

Jl.RS Islam XII No.14, Kec. Rappocini. Makassar

J1. Bumi Karsa Blok H2 No.9E, (Komp. IDI Pettarani), Kec. Panakkukang. Makassar

Jl.Perintis Kemerdekaan KM 16 No.2 Lobby Area, Kec.

Tamalanrea. Makassar

Jl.Abd.DG.Sirua Lr.5 / 18 A, Kec. Manggala. Makassar
Catering

Catering

Catering

Dapur Hotel

Dapur Hotel

Catering

Catering

Catering

Catering

Catering

Catering

Dapur Hotel

Catering
Bersertifikat Halal

Bersertifikat Halal

Bersertifikat Halal

Bersertifikat Halal

Bersertifikat Halal

Bersertifikat Halal

Bersertifikat Halal

Bersertifikat Halal

Bersertifikat Halal

Bersertifikat Halal

Bersertifikat Halal

Bersertifikat Halal

Bersertifikat Halal
Pada Tabel 4, menunjukkan bahwa restoran yang ada saat ini di Kota Makassar sekitar 2.274 restoran, kemudian data yang didapatkan oleh penulis dari LPPOM MUI mengenai restoran yang bersertifikat halal hanya berjumlah 25 restoran atau rumah makan khususnya di Kota Makassar. Hal tersebut, menunjukkan bahwa pelaku usaha restoran yang ada di Kota Makassar hanya sebagian kecil yang telah memiliki sertifikat halal. Padahal sertifikat halal ini merupakan sesuatu yang sangat penting bagi restoran sebagai pelaku usaha maupun bagi konsumen. Karena sertifikat halal ini merupakan bukti bahwa pelaku usaha menyajikan produk makanan yang halal kepada konsumen. Sehingga hal tersebut tidak merugikan pihak konsumen.

Dari data tersebut dapat dilihat bahwa tingkat kesadaran pelaku usaha dalam memperoleh sertifikat halal masih sangat rendah. Restoran yang ada saat ini begitu banyak dan terus berkembang, tetapi yang memiliki sertifikat halal masih jauh dari harapan. Bila dibandingkan dengan banyaknya restoran yang ada saat ini, dapat terlihat dengan jelas bahwa belum dapat terpenuhinya hak-hak konsumen atas informasi produk halal pada restoran yang ada di Kota Makassar.

Pelaku usaha restoran yang ada di Kota Makassar masih banyak yang belum memiliki sertifikat halal. Hal ini tentu saja merupakan pelanggaran. Karena berdasarkan aturan yang ada yakni UU JPH, pelaku usaha makanan diwajibkan memiliki sertifikat halal. Hal itu penting sebagai bentuk pemenuhan hak konsumen atas keaman dari makanan yang dapat merugikan khususnya umat Islam. Ketidakadaan sertifikat halal ini, tentu saja mempunyai alasan tersendiri. Para pelaku usaha restoran yang tidak memiliki sertifikat halal dari LPPOM MUI. Pelaku usaha restoran banyak merasa kesulitan, ketika ingin mendapatkan sertifikat halal untuk produk makanan yang mereka sajikan bagi konsumen. Seperti yang dikatakan oleh Dani selaku Manajer restoran (wawancara, 24 Agustus 2019) bahwa: "Sebagai pelaku usaha restoran tingkat persaingan sangatlah tinggi. Karena dalam proses ingin mendapatkan sertifikat halal harus memberikan semua nama menu yang ada. Dalam satu menu harus memberikan rincian bahan-bahan yang digunakan tanpa terkecuali. Di sinilah kemudian yang menjadi masalah, ada resep yang menjadi sangat rahasia. Sehingga memiliki ketakutan dan tidak ingin mendaftarkan restoran ke LPPOM MUI."
Ketakutan pelaku usaha akan bocornya resep rahasia yang menjadi salah satu masalah. Karena ketakutan tersebut, membuat pelaku usaha tidak mendaftarkan restorannya ke LPPOM MUI. Salah satu masalah lain yang dirasakan oleh pelaku usaha adalah merasa terbebani ketika ingin mendaftarkan restorannya ke LPPOM MUI. Sementara menurut Yanto selaku karyawan Restoran New Ujung Pandang (wawancara, 24 Agustus 2019) bahwa: "Untuk mendapatkan sertifikat halal, beban yang dirasakan sebagai pelaku usaha restoran, yaitu pada bagian pendaftaran dengan mengeluarkan biaya yang cukup besar. Sehingga membuat pelaku usahaberpikir untuk mendaftarkan restoran ini. Serta merasa takut akan menimbulkan kerugian akibat biaya pendaftaran dan lain-lainnya."

Pada Pasal 44 ayat (1) UUJPH disbutkan bahwa "biaya Sertifikasi Halal dibebankan kepada Pelaku Usaha yang mengajukan permohonan Sertifikat Halal." UU tersebut mengatakan dibebankan kepada pelaku usaha, yang di mana biaya untuk mendapatkan sertifikat halal dibayar sesuai banyaknya menu yang didaftarkan ke LPPOM MUI. Untuk mendapatkan kehalalan produknya, itulah salah satu beban yang dirasakan oleh pelaku usaha sehingga berfikir untuk mendaftarkan restorannya.

Sentara itu, menurut Maimunah selaku pemilik restoran Kayangan (wawancara, 25 Agustus 2019) bahwa: "Meskipun UU telah mengatur mengenai kewajiban bagi pelaku usaha dalam memperdagangkan produk di dalam negeri harus bersertifikat halal. Tetapi mengapabelum juga mendaftarkan restoran ke LPPOM MUI, karena saya melihat tidak ada tindakan tegas yang diberikan oleh pihak yang berwenang kepada pelaku usaha yang melanggar khususnya produk yang diperdagangkan di dalam negeri harus bersertifikat halal. Khususnya pelaku usaha restoran."

Berdasarkan wawancara di atas, diketahui bahwa pelaku usaha masih menganggap UUJPH belum secara baik terlaksana. Sehingga pelaku usahapun belum mengambil tindak lanjut mengenai kehalalan produk yang diperdagangkannya. Adapun pelaku usaha yang sudah memilki sertifikat halal di bidang restoran hanya sedikit, bila dibandingkan dengan restoran yang ada saat ini. Pelaku usaha yang sudah terdaftar di LPPOM MUI kebanyakan dari usaha Catering, kemudian ada beberapa Dapur Hotel, yang 
bersertifikat halal. Menurut Marni Nur selaku Manager Catering CV. Condong Raos (wawancara, 7 Agustus 2019) bahwa: "Perbedaan yang dirasakan sebagai pelaku usaha catering sebelum dan sesudah memiliki sertifikat halal sangat tampak semenjak catering mendapatkan sertifikat halal, sejak saat itu, pelanggang yang datang jauh lebih banyak dan orderan pun semakin meningkat pesat. Dan kebanyakan konsumen yang menjadi pelanggan adalah yang beragama Islam."

Setelah medapatkan sertifikat halal pelaku usaha harus menjaga kehalalan menu yang sudah bersertifikat halal, kemudian memberikan informasi kepada konsumen bahwa makanan tersebut telah bersertifikat halal, sehingga membuat konsumen dapat menikmati makanan tersebut dengan nyaman dan tanpa ada keraguan dari hati konsumen yang mengkonsumsinya.

Ketakutan yang dirasakan oleh pelaku usaha ketika ingin mendaftarkan restorannya untuk disertifikasi halal. Menurut Kamsiah selaku Manager Catering CV. REZKY JAYA (wawancara, 25 Agustus 2019) bahwa: "Sebelum akhirnya mendaftarkan restoran ini ke LPPOM MUI untuk mendapatkan sertifikat halal pada produk.kekhawatiran akan resep rahasia yang digunakan dalam meracik masakan nantinya akan disalahgunakan oleh yang bertugas memeriksanya. Tetapi setelah mendapatkan informasi bahwa dalam UUJPH sudah ada ketentuan bagi pelanggar yang menyalagunakan kewenangannya dalam proses pemeriksaan. Sehingga segera mendaftarkan restoran ke LPPOM MUI untuk mendapatkan sertifikat halal."

Salah satu ketakutan pelaku usaha, yaitu tentang akan bocornya resep rahasia yang mereka miliki dalam proses membuat makanan. Kekhawatiran pelaku usaha tersebut, sudah di atur dalamPasal 57 UUJPH bahwa: "Setiap orang yang terlibat dalam penyelenggaraan proses JPH yang tidak menjaga kerahasiaan formula yang tercantum dalam informasi yang diserahkan Pelaku Usaha sebagaimana dimaksud dalam Pasal 43 dipidana dengan pidana penjara paling lama 2 (dua) tahun atau pidana denda paling banyak Rp. 2.000.000.000,00 (dua miliar rupiah)."

Sertifikat Halal MUI adalah fatwa tertulis yang dikeluarkan oleh MUI yang menjelaskan akan kehalalan suatu produk yang sudah sesuai dengan syari'at agama Islam. Sertifikat, ini merupakan syarat yang harus dipenuhi oleh pelaku usaha agar mendapatkan izin mencantumkan label halal pada kemasan produk dari instansi pemerintah yang berwenang. Pemberian Sertifikasi Halal MUI pada produk pangan, obat-obat, kosmetika dan produk lainnya dilakukan agar dapat memberikan kepastian mengenai status kehalalan produk tersebut, sehingga dapat menenteramkan batin konsumen dalam mengkonsumsinya. Kesinambungan proses produksi halal dijamin oleh produsen dengan cara menerapkan SJH.

Bagaimana proses produk halal (PPH) yang dilakukan dalam pemeriksaan suatu menu makanan untuk mendapatkan kehalalan produknya. Menurut Pasal 15 UUJPH Auditor Halal memilikitugas:

a. memeriksa dan mengkaji Bahan yang digunakan;

b. memeriksa dan mengkaji proses pengolahan Produk;

c. memeriksa dan mengkaji sistem penyembelihan;

d. meneliti lokasi Produk;

e. meneliti peralatan, ruang produksi, dan penyimpanan;

f. memeriksa pendistribusian dan penyajian Produk;

g. memeriksa sistem jaminan halal Pelaku Usaha; dan h. melaporkanhasil pemeriksaan dan/atau pengujian kepada LPH.

Konsumen harus memiliki tingkat kesadaran yang lebih tinggi akan pentingnya suatu produk yang bersertifikat halal. Pada Pasal 21 ayat (1) dan (2) UUJPH bahwa:

a. Lokasi, tempat, dan alat PPH wajib dipisahkan dengan lokasi, tempat, dan alat penyembelihan, pengolahan, penyimpanan, pengemasan, pendistribusian, penjualan, dan penyajian Produk tidak halal.

b. Lokasi, tempat, dan alat PPH sebagaimana dimaksud pada ayat (1) wajib: (1) dijaga kebersihan dan higienitasnya; (2) bebas dari najis; dan (3) bebas dari Bahan tidak halal.

Undang-undang tersebut di atas, menunjukkan bahwa dalam proses untuk mendapatkan sertifikat halal pada produk pagan yang dimiliki oleh pelaku usaha begitu sulit dan melewati banyak proses. Sehingga akan lebih aman bagi konsumen dalam mengkonsumsi suatu produk yang telah bersertifikat halal. BPJPH pada Pasal 6 UUJPH bahwa menerbitkan dan mencabut Sertifikat Halal dan Label Halal pada Produk. Salah satu pentingnya tingkat kesadaran akan peran masyarakat dalam membantu BPJPH mengawasi produk yang beredar seperti yang sudah ada di dalam UUJPH mengenai pengawasan serta peran masyarakat dan dapat melaporkan ke BPJPH, sehingga dapat di tindaklanjuti oleh BPJPH bagi pelaku usaha yang melanggar ketentuan UU yang sudah ditetapkan.

\section{c) Konsumen}

Konsumen harus mendapatkan hak-haknya. Seperti yang kita ketahui di Indonesia mayoritas penduduknya adalah beragama Islam, begitu pula di Kota Makassar. Dalam ajaran Agama Islam, setiap muslim diwajibkan mengkomsumsi produk halal dan juga menghindari produk-produk syubhat, yaitu produk yang tidak jelas kehalalannya. Hal tersebut merupakan bagian dari konsekuensi dalam menjalankan ajaran agama yang diyakini.Kebebasan serta jaminan untuk menjalankan ajaran agama di Indonesia dilindungi oleh konstitusi.

Mengacu pada Pasal 4 huruf a UUPK yang menyebutkan bahwa "hak atas kenyamanan, keamanan, dan keselamatan dalam mengkonsumsi barang dan/atau jasa. Hak atas, kenyamanan, keamanan dan keselamatan mengandung pengertian bahwa konsumen berhak mendapatkan produk yang nyaman, aman dan yang memberi keselamatan." Oleh karena itu, konsumen harus mendapatkan perlindungan dari segala sesuatu yang dapat membahayakan dan mengancam kesehatan, jiwa, dan harta bendanya disebabkan karena menggunakan atau mengkonsumsi makanan dan minuman di restoran. Dengan demikian, maka setiap produk, baik dari segi komposisi bahannya, dari segi desain harus diarahkan untuk memenuhi standar keamanan dan keselamatan bagi konsumen.

Meskipun demikian, dalam UUPK tidak saja mengatur perihal hak konsumen, akan tetapi juga diatur kewajiban konsumen sebagaimana diatur dalam Pasal 5 huruf a UUPK bahwa kewajiban konsumen adalah: Membaca atau mengikuti petunjuk informasi dan prosedur pemakaian atau pemanfaatan barang dan/atau jasa, demi keamanan dan keselamatan. Salah satu faktor ketidakterpenuhan hak konsumen atas informasi yang diberikan oleh pelaku usaha, apakah sudah sesuai atau belum sesuai prosedur seperti yang ada di dalam UU tersebut. Banyak juga dari pihak konsumen itu sendiri, dengan sengaja mengabaikan kesalahan-kesalahan yang dilakukan oleh pelaku 
usaha. Sehingga semakin kurang tingkat kesadaran dari pihak pelaku usaha dalam memberikan informasi produk halal kepada konsumen.

Seperti yang dikatan oleh Umar yang merupakan salah satu konsumen restoran atau rumah makan di Kota Makassar (wawancara, 2 Agustus 2019) bahwa: "Kami sebagai pelanggan rumah makan atau restoran, sebelum membeli makanan tidak bertanya atau memeriksa apakah ada sertifikat halal karena di sini (Kota Makassar) mayoritas Islam, penjual makanan pun rata-rata orang Islam. Jadi tidak perlu lagi ditanyakan. Karena dalam pandangan kami, makanannya pasti halal karena yang menjual orang Islam.'

Jika dicermati hasil wawancara tersebut di atas, dapat diketahui bahwa masyarakat tidak memperhatikan makanan yang dibelinya di restoran karena mereka menganggap makanan yang dijual di restoran aman karena yang menjual adalah orang Islam yang pasti paham akan barang halal. Ini sebenarnya sangat rawan karena kesadaran masyarakat yang masih kurang, sehingga daya kritis pun kurang. Hal ini bisa berdampak pada adanya produk yang tidak halal yang mereka komsumsi. Kurangnya kesadaran tersebut bisa dimanfaatkan oleh pelaku usaha restoran untuk menjual produk yang tidak halal karena memanfaatkan ketidaktahuan, atau kurang kritisnya konsumen dalam memilih produk makanan.

Padahal berdasarkan informasi yang penulis dapatkan ternyata di Kota Makassar masih banyak restoran yang belum memilki sertifikat halal. Adapun hasil penelitian yang dilakukan oleh penulis, terkait restoran yang ada, untuk mengetahui berapa banyak restoran yang ada di Kota Makassar. Peneliti juga telah menyebarkan angket kepada produsen untuk melihat tanggapan-tanggapan mengenai sertifikat halal:

\section{Tabel 5}

Tanggapan Responden Terkait Restoran Yang Pernah DiKunjungi Apakah Memiliki Sertifikat Halal

\begin{tabular}{clcc}
\hline No & Jawaban Responden & Frekuensi & Persentase \\
\hline 1 & Sudah & 7 & $14 \%$ \\
2 & Belum & 23 & $46 \%$ \\
3 & Tidak Tahu & 20 & $40 \%$ \\
\hline & Jumlah & 50 & $100 \%$
\end{tabular}

Sumber : Data Primer 2019

Dari tabe tabel di atas, diketahuai tanggapan responden mengenai restoran yang pernah dikunjungi yang ada di Kota Makassar. Apakah sudah memiliki sertifikat halal atau tidak, yang menjawab sudah memiliki sertifikat halal sebanyak 7 responden (14\%), kemudian yang menjawab belum memiliki sertifikat halal sebanyak 23 responden (46\%), dan yang menjawab tidak tahu mengenai ada atau tidaknya sertifikat halal pada restoran tersebut sebanyak 20 responden (40\%). Dari hasil yang didapat oleh penulis, yaitu responden yang menjawab belum memiliki sertifikat halal pada restoran yang pernah dikunjungi 23 responden (46\%), dari hasil tersebut menunjukkan bahwa restoran yang ada di Kota Makassar masih banyak yang belum memiliki sertifikat halal.
Tabel 6

Tanggapan Responden Terkait Apakah Pelaku Usaha Menyampaikan Atau Tidak Kepada Konsumen Mengenai Informasi Produk Halal yang Disajikan

\begin{tabular}{clcc}
\hline No & $\begin{array}{c}\text { Jawaban } \\
\text { Responden }\end{array}$ & Frekuensi & Persentase \\
\hline 1 & Ya & 9 & $18 \%$ \\
2 & Tidak & 34 & $68 \%$ \\
3 & Tidak Tahu & 7 & $14 \%$ \\
\hline & Jumlah & 50 & $100 \%$ \\
\hline
\end{tabular}

Sumber : Data Primer 2019

Berdasarkan tabel di atas, tanggapan responden terkait apakah pelaku usaha menyampaikan atau tidak kepada konsumen mengenai informasi produk halal yang disajikan oleh pelaku usaha, yang menjawab Ya diinformasikan produknya memiliki sertifikat halal sebesar 9 responden (18\%), adapun yang menjawab tidak diinformasikan produknya memiliki sertifikat halal sebanyak 34 responden (68\%), dan yang menjawab tidak tahu mengenai diinformasikannya tentang produknya memiliki sertifikat halal atau tidak sebanyak 7 responden (14\%). Dari hasil di atas, menunjukkan bahwa pelaku usaha yang tidak menyampaikan informasi produk yang disajikannya sekitar 34 responden (68\%), yang dimana, angka tersebut menunjukkan begitu banyak restoran di Kota Makassar tidak memenuhi hak-hak konsumen dalam menginformasikan produk yang disajikan halal atau tidak.

Tabel 7

Tanggapan Responden Terkait Apakah Restoran Lebih Baik Memiliki Sertifikat Halal Atau Tidak Memiliki Sertifikat Halal

\begin{tabular}{clcc}
\hline No & $\begin{array}{c}\text { Jawaban } \\
\text { Responden }\end{array}$ & Frekuensi & Persentase \\
\hline 1 & Memiliki & 41 & $82 \%$ \\
2 & Tidak Memiliki & 3 & $6 \%$ \\
3 & Tidak Tahu & 6 & $12 \%$ \\
\hline & Jumlah & 50 & $100 \%$ \\
\hline
\end{tabular}

Sumber : Data Primer 2019

Berdasarkan tabel di atas, tanggapan responden terkait apakah restoran lebih baik memiliki sertifikat halal atau tidak memiliki sertifikat halal, yaitu sebagian besar yang menjawab harus memiliki sertifikat halal pada restoran yang ada di Kota Makassar sebanyak 41 responden (82\%), adapun responden yang mengatakan tidak harus memiliki sertifikat halal sebanyak 3 responden (6\%), sedangkan yang menjawab tidak tahu ada 6 responden (12\%). Berdasarkan hasil yang didapat oleh penulis sehubungan dengan haruskah pelaku usaha di bidang restoran memiliki atau tidak sertifikat halal dan yang menjawab harus memiliki sertifikat halal sekitar 41 responden $(82 \%)$, hasil tersebut menunjukkan keinginan konsumen untuk dipenuhi hak-haknya atas informasi produk halal yang akan dikonsumsinya 


\section{KESIMPULAN}

Hasil penelitian dapat disimpulkan bahwa pelaksanaan pemenuhan hak konsumen atas informasi produk halal pada restoran di Kota Makassar dilaksanakan dengan cara sosialisasi dan pemenuhan hak informasi kepada masyarakat. Meski demikian, pelaksanan pemenuhan hak konsumen atas informasi produk halal pada restoran di Kota Makassar tersebut, belum berjalan sebagaimana mestinya. Faktor-faktor yang mempengaruhi ketidakterpenuhan hak konsumen atas informasi produk halal pada Restoran di Kota Makassar adalah (1) Pemerintah dalam hal ini Badan Pelaksana Jaminan Produk Halal (BPJPH) tidak bisa melaksanakan fungsinya dalam melakukan pembinaan dan pengawasan terhadap jaminan produk halal di Kota Makassar mengingat lembaga ini hanya ada di Pusat, tidak ada di daerah Kabupaten/Kota, (2) Restoran/Pelaku usaha yang ada di Kota Makassar cenderung mengabaikan hak konsumen dengan tidak menyampaikan keadaan kehalalan produk yang mereka sajikan, dan (3) Konsumen cenderung melihat dari sisi pemilik dan pegawai restoran. Umumnya, mereka tidak memiliki sikap kritis, sehingga kadang abai dari memperhatikan masalah kehalalan produk yang disediakan di restoran. Padahal itu dapat merugikan mereka sebagai konsumen.

\section{DAFTAR PUSTAKA}

Ahmadi Miru \& Sutarman Yodo, Hukum Perlindungan Konsumen, Raja Grafindo Persada, Jakarta, Cet. ke-8, 2015

Amin, M. (2013). "Halal Berlaku Untuk Seluruh Umat". Jurnal Halal Nomor. 1. Th. XVI, LPPOM MUI.

Mashudi. (2015). Konstruksi Hukum dan Respons Masyarakat Terhadap Sertifikasi Halal: Studi Socio-Legal Terhadap Lembaga Pengkajian Pangan, Obat-Obatan, Dan Kosmetika Majelis Ulama Indonesia. Yogyakarta: Pustaka Pelajar.

Mubarok, J. (2006). Hukum Islam: Konsep, Pembaruan dan Teori Penegakan. bandung: Benang Merah.

Hazairin. (1990). Demokrasi pancasila. Jakarta: Rineka Cipta.

Peraturan Pemerintah Nomor 31 Tahun 2019 tentang Peraturan Pelaksanaan Undang-undang Nomor 33 Tahun 2014 tentang Jaminan Produk Halal

Peraturan Pemerintah Nomor 58 Tahun 2001 tentang Pembinaan dan Pengawasan Penyelenggaraan Perlindungan Konsumen

Undang-Undang Negara Republik Indonesia Tahun 1945

Undang-Undang Nomor 8 Tahun 1999 tentang Perlindungan Konsumen

Undang-Undang Nomor 33 Tahun 2014 tentang Jaminan Produk Halal.

Zulham. (2013). Hukum Perlindungan Konsumen. Jakarta: Kencana Prenada Media Group 